KHAZANAH MULTIDISIPLIN

VOL 1 NO 22020

https://journal.uinsgd.ac.id/index.php/kl

\title{
KONTROVERSI HADIS AMALAN SUNNAH BULAN RAJAB
}

\author{
Siti Rahmah', Wahyudin Darmalaksana ${ }^{2}$ \\ 1,2Jurusan Ilmu Hadis, Fakultas Ushuluddin, UIN Sunan Gunung Djati \\ Bandung, Indonesia \\ Email: strhmaah@gmail.com
}

Diterima : 5 November 2020, Revisi : 15 November 2020 Disetujui : 29 November 2020

\begin{abstract}
This study aims to discuss the controversy surrounding the hadith practice of the month of Rajab among the Muslim community. This research is a type of qualitative research that applies literature study to interpret the hadith text using the sharah hadith approach. The results and discussion of this research include the historical meaning and meaning of the naming of the month of Rajab in Islam, hadiths regarding the practice of the month of Rajab, and analysis of the law of the practice of the month of Rajab which is controversial among Muslims. This research concludes that based on available references and controversial traditions in the practice of the Sunnah of the month of Rajab, it is clear that there is no special practice during the month of Rajab but it is highly recommended that every Muslim as a servant of Allah always increases devotion to Allah and increases practice of worship whenever and wherever they are. This study recommends further research on the practice of the sunnah of the month of Rajab through hadith theory with a more indepth living hadith approach.
\end{abstract}

Keywords: Fasting, Hadith, Month of Rajab, Practice, Sunnah

\begin{abstract}
ABSTRAK
Penelitian ini bertujuan untuk membahas kontroversi seputar hadis amalan bulan Rajab di kalangan masyarakat muslim. Penelitian ini merupakan jenis penelitian kualitatifyang menerapkan studi pustaka untuk melakukan interpretasi terhadap teks hadits dengan menggunakan pendekatan syarah hadis. Hasil dan pembahasan penelitian ini mencakup pengertian dan makna sejarah penamaan bulan Rajab dalam Islam, hadits-hadits mengenai amalan bulan Rajab, dan analisishukum amalanbulan Rajab yang kontroversial di kalangan umat muslim. Penelitian ini menyimpulkan bahwa berdasarkan referensireferensi yang tersedia serta hadis-hadis yang menjadi kontroversi dalam amalan Sunnah bulan Rajab dengan tegas menyatakan tidak terdapat amalan khusus pada saat bulan Rajab tetapi sangat dianjurkan setiap umat Islam sebagai hamba Allah untuk selalu meningkatkan ketakwaan kepada Allah dan meningkatkan amalan ibadah kapanpun dan dimanapun berada. Penelitian ini merekomendasikan untuk penelitian lebih lanjut tentang amalan sunnah bulan Rajab melalui teori hadis dengan pendekatan living hadis secara lebih mendalam.

Kata Kunci: Amalan, Bulan Rajab, Hadis, Puasa, Sunnah
\end{abstract}

\section{PENDAHULUAN}

Amalan di bulan Rajab masih menyisahkan perselisihan di sebagian masyarakat Indonesia, khususnya berkenaan dengan amalan puasa sunnah. Puasa sendiri adalah salah satu bentuk peribadatan yang telah 


\section{KHAZANAH MULTIDISIPLIN}

VOL 1 NO 22020

https://journal.uinsgd.ac.id/index.php/kl

ditetapkan menjadi upacara ibadah berbagai agama (Syam, 2010). Puasa diakui sebagai salah satu ibadah yang memiliki banyak manfaat, keutamaan, dan keajaiban yang luar biasa bagi siapapun yang menjalankannya (Syarbini, 2014). Puasa merupakan salah satu ibadah yang memiliki nilai pahala besar dalam syari'at Islam (Kurniawati). Puasa sunnah Rajab adalah puasa yang dilaksanakan pada bulan Rajab (Achmad, 2007). Diriwayatkan bahwa Nabi Nuh As. mengendarai bahteranya pada hari itu, beliau memerintahkan orang-orang yang bersamanya untuk berpuasa, dan siapa yang berpuasa pada hari ini, api neraka akan dijauhkan darinya dengan jarak satu tahun (Al-Qummi, 2008). Namun sebagian masyarakat muslim menolak puasa sunnah di bulan Rajab dengan alasan hadis-hadis yang mendasarinya merupakan hadis dhaif dan bahkan palsu dengan menyatakan bagi para pelakunya sebagai bid'ah (Sarwat). Mengingat adanya pandangan kalangan ulama yang saling silang pendapat, maka pelaksanaan puasa sunnah di bulan Rajab menjadi subjek yang masih kontroversial bagi sebagian masyarakat awam di Indonesia.

Penelitian terdahulu telah dilakukan dengan baik oleh para peneliti terdahulu. Antara lain penelitian yang dilakukan oleh Dhohir (2019), dengan judul "Kualitas Hadis-Hadis Viral tentang Keutamaan Bulan Rajab," dalam Jurnal Studi Ilmu al-Qur'an dan Tafsir. Penelitian ini membahas tentang hadis-hadis yang berhubungan dengan bulan Rajab yang viral di sosial media. Hasil pembahasan penelitian ini menyangkut kualitas hadis keutamaan bulan Rajab. Penelitian ini menilai kualitas hadis berdasarkan empat aspek, yaitu: a) mencatat semua para perawi, biografinya serta guru-gurunya; b) menggunakan kaidah jarh wa ta'dil; c) ada atau tidaknya syadz dan illat; dan d) membandingkan hadis tersebut dengan al-Qur'an dan hadis lain. Penelitian ini menyimpulkan bahwa terdapat dua hadis berkualitas shahih dari segi sanad maupun matan. Hadis-hadis ini berkualitas shahih karena periwayat hadis bersambung, kualitas periwayat tsiqah, yakni 'adil dan dabit, matan tidak syadz dan tidak ada 'illat. Akan tetapi, ada satu hadis yang berkualitas dhaif dari segi sanad. 


\section{KHAZANAH MULTIDISIPLIN}

VOL 1 NO 22020

https://journal.uinsgd.ac.id/index.php/kl

Sebab, di antara para periwayat hadis ada yang dinilai negatif (jarh). Selebihnya, hadis tersebut dari sisi sanad juga hanya terdapat satu jalur periwayatan sehingga tidak ada jalur lain yang dapat menguatkan, meskipun hadis dimaksud diakui shahih dari segi matannya. Dari hasil penelitian sanad ditemukan bahwa hadis tersebut dalam keadaan tidak tersambung sanadnya karena ada salah satu perawi yang kedudukannya berstatus majhul al-hal. Oleh karena itu, hadis ini berkualitas dha'if. Namun beberapa ulama berpendapat bahwa hadis dha'if yang merupakan fadailul 'amal dapat dijadikan amalan Islam, akan tetapi tidak dapat digunakan secara mutlak (Dhohir, 2019). Penelitian ini berlandaskan pada kerangka paradigmatik kesahihan hadis (Darmalaksana, 2018). Ada pula penelitian yang dilakukan oleh Arifin (2017), dengan judul "Menguji Autentisitas Hadis-Hadis tentang Pengamalan Puasa Rajab: Kajian terhadap Sanad dan Matan." Pembahasan penelitian ini meliputi kualitas sanad dan matan hadis-hadis tentang pengamalan puasa bulan Rajab. Penelitian ini merekomendasikan bahwa penggunaan hadis sebagai dasar penetapan sebuah hukum dibutuhkan penggalian derajat kualitas hadis (Arifin, 2017). Penelitian ini sejalan dengan pandangan tentang urgensi hadis dalam ranah kontroversi sebagai sumber hukum (Darmalaksana, Pahala, \& Soetari, 2017).

Kerangka berpikir penelitian ini disusun berdasarkan hasil-hasil penelitian terdahulu untuk mendukung temuan sebelumnya. Kerangka berpikir penelitian ini memandang perlu menegaskan kembali tentang penjelasan bulan Rajab dalam Islam, termasuk penamaan bulan Rajab dimana pada bulan tersebut kaum Jahiliyah menahan diri untuk tidak melakukan permusuhan (Dhohir, 2019). Bulan Rajab disebut bulan haram yang bermakna bulan dilarang adanya peperangan. Sedangkan makna lebih luas dari makna haram adalah larangan melakukan peperangan, pembunuhan, kedzaliman, dan larangan berbuat dosa (Setiyanto, 2016). Berdasarkan catatan sejarah, bulan yang disebut Rajab ini tampak dimuliakan oleh kaum Arab yakni dengan cara menyembelih seekor anak 
KHAZANAH MULTIDISIPLIN

VOL 1 NO 22020

https://journal.uinsgd.ac.id/index.php/kl

unta pertama yang lahir dari induknya (Dhohir, 2019). Dalam referensi Islam banyak ditemukan hadis-hadis yang berkaitan dengan anjuran untuk melakukan puasa pada bulan Rajab (Anshary, 2013). Berdasarkan teks hadis tersebut terdapat redaksi hadis tentang amalan puasa bulan Rajab (Arifin, 2017). Imam Nawawi menjelaskan hadis dimaksud bahwatidak ada larangan dan tidak ada pula anjuran secara khusus puasa pada Rajab, tetapi hukumnya sama seperti bulan-bulan lainnya, dan tidak ada ketetapan larangan dan kesunnahan untuk puasa Rajab tetapi asalnya puasa adalah sunnah (Mohd, 2018). Sebagian pendapat menyatakan bahwa hal yang tidak diperkenankan adalah berpuasa penuh sepanjang bulan Rajab, sedangkan banyak berpuasa di bulan Rajab tidaklah dipersoalkan (Rosidin, 2016). Dalam hal ini, para ulama berbeda pendapat mengenai hukum melaksanakan puasa Rajab (Mohd, 2018). Sebagian ulama mengemukakan bahwa pada bulan Rajab pada dasarnya tidak ada amalan yang dikhususkan,jika pun ada maka hal itu perlu untuk diklarifikasi keshahihan hadis atau sumbernya, namun anjuran untuk berbuat kebaikan dan menjauhi kemaksiatan di dalamnya jelas ada, hanya saja bukan berarti mengkhususkan beberapa amal tertentu (Setiyanto, 2016). Hukum puasa di bulan Rajab sesuai kesepakatan tiga Imam Mazhab adalah sunah, kecuali Imam Hambali yang berpendapat bahwa puasa pada bulan tersebut secara tersendiri hukumnya makruh, namun jika tidak berpuasa di pertengahan bulan maka menjadi tidak makruh (Ahmad, 2007). Kerangka berpikir ini menekankan urgensi pengkajian hadis dari berbagai disiplin keilmuan yang relevan (Darmalaksana, 2020).

Berdasarkan kerangka berpikir di atas, penelitian ini berusaha menyusun formula penelitian, yaitu rumusan masalah, pertanyaan penelitian, dan tujuan penelitian (Darmalaksana, 2020). Rumusan masalah penelitian ini adalah terdapat kontroversi hadis amalan bulan Rajab di kalangan masyarakat muslim. Berdasarkan rumusan masalah tersebut maka pertanyaan penelitian ini secara terperinci, yakni bagaimana bulan Rajab dalam Islam, bagaimana hadis-hadis tentang puasa sunnah bulan 
KHAZANAH MULTIDISIPLIN

VOL 1 NO 22020

https://journal.uinsgd.ac.id/index.php/kl

Rajab, dan terakhir sebagai pertanyaan utama dalam penelitian ini, yaitu bagaimana kontroversi seputar hadis amalan sunnah bulan Rajab di kalangan masyarakat muslim. Tegaslah bahwa tujuan penelitian ini adalah untuk membahas kontroversi hadis amalan Sunnah bulan Rajab di kalangan masyarakat muslim. Penelitian ini diharapkan dapat memberikan manfaat dan kegunaan khususnya sebagai rujukan bagi kalangan peminat bidang hadis dan sebagai pengayaan khazanah multidisiplin pengetahuan Islam.

\section{METODE PENELITIAN}

Penelitian ini merupakan jenis kualitatif dengan menerapkan studi pustaka (Darmalaksana, 2020). Mula-mula sumber kepustakaan dihimpun dan dikategorikan sesuai pertanyaan-pertayaan penelitian. Data sumber kepustakaan yang telah dikategorisasi kemudian ditampilkan sebagai temuan penelitian. Selanjutnya, data tersebut diabstraksikan secara apa adanya sehingga terbentuk menjadi fakta penelitian (Darmalaksana, 2020). Penulis melakukan interpretasi terhadap fakta penelitian tersebut untuk menghasilkan informasi atau pengetahuan. Pada tahap interpretasi digunakan metode, pendekatan, dan analisis syarah hadis (Darmalaksana, 2020) mengenai puasa sunnah di bulan Rajab. Analisis ini diakui sebagai perangkat yang cukup populer dalam kajian hadis (Darmalaksana, 2020).

\section{HASIL DAN PEMBAHASAN}

\section{Bulan Rajab dalam Islam}

Bulan Rajab adalah bulan ke-7 dalam tahun hijriah (Shohibah, 2012). Bulan Rajab merupakan salah satu bulan di antara dua belas bulan yang dimuliakan dengan dimulai dari Muharram dan diakhiri dengan Dzulhijah (Dhohir, 2019). Syekh Zainuddin al-Malibari dalam kitab Fathul Mu'in menjelaskan bahwa bulan paling utama setelah Ramadhan ialah bulan-bulan yang dimuliakan Allah dan Rasul-Nya, dimana bulan paling utama ialah Muharram, Rajab, Dzulhijah, Dzulqa'dah, dan Sya'ban (Azkiya, 
KHAZANAH MULTIDISIPLIN

VOL 1 NO 22020

https://journal.uinsgd.ac.id/index.php/kl

2019). Bulan Rajab merupakan salah satu bulan haram sebagaimana disebutkan dalam al-Qur'an surah at-Taubah ayat 36 dan disebutkan dalam hadits Rasulullah Saw (Asiyah, 2016) berupa hadis Mutafaqun Alaih tentang nama bulan haram atau suci (Setiyanto, 2016).

Rajab terdiri dari tiga huruf akronim yaitu $R a$ dari kalimah rahmatullah atau rahmat Allah, Jim dari kalimah jinayatul 'abd atau kesalahan hamba Allah, dan $B a$ dari kalimah birullah atau kebijakan Allah (Alviennoer, 2010). Kata "Rajab" diambil dari Bahasa Arab dengan lafadz (Dhohir, 2019) yang bermakna agung dan terhormat (Asiyah, 2016). Rajab adalah bulan yang diagungkan pada masa Jahiliyah (Anshary, 2013). Masyarakat Arab sangat memuliakan bulan ini dengan menghentikan dan melarang peperangan selama bulan Rajab. Nama bulan Rajab berasal dari kata "rajaba asy-Syai'a" yang artinya, "habahu wa 'azhzhamahu" atau memuliakan dan menghormati (Al-Ballawi, 2016). Adapun mengenai keutamaannya banyak disebutkan dalam hadis dari para imam (Zahra, 2005).

Penamaan bulan Rajabkarena pada bulan tersebut mereka menahan diri untuk tidak melakukan permusuhan (Dhohir, 2019). Ada yang mengatakan Rajab artinya adalah berhenti dari perang (Al-Ballawi, 2016). Sampai-sampai mereka berusaha menghindari peperangan dan tidak membolehkan terjadinya pertempuran pada bulan Rajab (Anshary, 2013). Pada bulan tersebut orang Islam dilarang menganiaya diri sendiri dengan mengerjakan perbuatan yang dilarang (Asiyah, 2016). Bulan Rajab disepakati sebagai bulan gencatan senjata, dimana diharamkan melakukan perang pada bulan suci tersebut (Sodiqin, 2008). Makna dari haram pada awalnya adalah bulan dilarang adanya peperangan, namun makna lebih luas lagi dari makna haram adalah larangan melakukan peperangan, pembunuhan, kedzaliman, dan larangan berbuat dosa, sehingga ada ulama yang berpendapat bahwa melakukan dosa di bulan haram maka dosanya lebih berat lagi (Setiyanto, 2016). Bulan ini juga dinisbatkan kepada suku Mudhar, karena suku ini memiliki komitmen yang cukup tinggi dalam 
KHAZANAH MULTIDISIPLIN

VOL 1 NO 22020

https://journal.uinsgd.ac.id/index.php/kl

mengagungkan bulan Rajab, berbeda dengan suku lainnya (Alviennoer, 2010).

Menurut lembar sejarah, bulan yang lazim disebut Rajab ini sungguh sangat dimuliakan oleh kaum Arab pada umumnya dengan ritual penyembelihan seekor anak unta dengan syarat yang pertama lahir dari induknya. Mereka dahulu juga biasa menyembelih binatang sembelihan yang dinamakan al-Athirah, yaitu kambing yang disembelih sebagai persembahan bagi berhala-berhala mereka, sedangkan darahnya dituangkan di atas kepala berhala itu. Lalu Islam membatalkan perbuatan itu berdasarkan riwayat Shahihain, "tidak ada Fara' yakni anak pertama dari unta atau kambing yang disembelih sebagai persembahan bagi berhala dan 'Athirah yaitu hewan yang disembelih pada sepuluh hari pertama dari bulan Rajab sebagai persembahan bagi berhala, juga dikenal dengan Rajabiyah (Dhohir, 2019).

Pada bulan ini dilarang melakukan peperangan dan pada bulan ini pula pintu Ka'bah dibuka sebagaimana sabda dari Rasulullah Saw berkenaan dengan bulan Rajab (Shohibah, 2012). Bulan Rajab merupakan bulan persiapan mental spiritual seorang hamba untuk mengabdi sepenuhnya secara spiritual kepada Allah untuk Ramadhan nantinya (Sholikhin, 2010). Sebagian ulama salaf berkata, bulan Rajab adalah bulan menanam, Sya'ban bulan menyirami tanaman, sedangkan bulan Ramadhan adalah bulan memetik atau memanen (Dhohir, 2019). Sejak awal bulan ini hingga akhir, Allah memberikan tiga pemberian kepada manusia, yaitu rahmat tanpa azab, kedermawanan tanpa kebakhilan dan kebaikan (kesuburan) tanpa kekeringan (Al-Qahthani, 2004). Karena itu, sebagian umat muslim berusaha melaksanakan puasa sunnah di bulan ini. Puasa sunnah sendiri adalah puasa yang dilakukan atau dianjurkan oleh Nabi Muhammad Saw. di luar puasa wajib di bulan Ramadhan (Khozinatin, 2017). Adapun puasa sunnah bulan Rajab adalah puasa sunah yang dilakukan pada bulan Rajab (Achmad, 2007). 
KHAZANAH MULTIDISIPLIN

VOL 1 NO 22020

https://journal.uinsgd.ac.id/index.php/kl

\section{Hadis-Hadis Puasa Sunnah Bulan Rajab}

Islam memiliki banyak referensi dari hadis-hadis yang berkaitan dengan anjuran untuk melakukan puasa pada bulan Rajab. Anjuran tersebut diklaim sebagai anjuran Rasulullah Saw kepada umatnya, karena diyakini bulan Rajab memiliki keutamaan-keutamaanyang melebihi bulanbulan yang lain. Oleh sebab itu, diyakini bahwa Rasulullah Saw menganjurkan umatnya berpuasa pada bulan Rajab tersebut (Anshary, 2013).

Sebagaimana diriwayatkan oleh Imam Abu Daud, Nabi Saw bersabda:

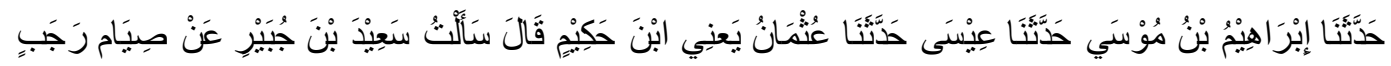

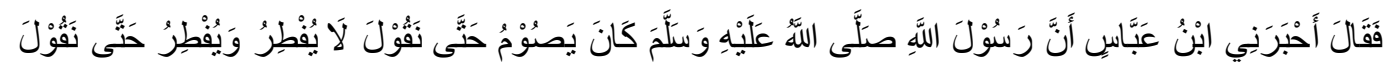

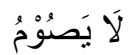

Artinya: Telah menceritakan kepada kami Ibrahim bin Musa, telah menceritakan kepada kami Isa, telah menceritakan kepada kami Utsman bin Hakim, ia berkata saya bertanya kepada Sa'id bin Jubair, mengenai puasa Rajab. Ia berkata telah mengabarkan kepadaku Ibnu Abbas, bahwa Rasulullah Saw pernah berpuasa hingga kami mengatakan beliau tidak berbuka. Dan beliau berbuka hingga kami mengatakan beliau tidak puasa (As-Sijistani, 2007).

Berdasarkan teks hadis di atas, jelas bahwa hadis ini diambil dari kitab Sunan Abu Dawud, sehingga kedudukan Abu Dawud dalam sanad hadis ini sebagai mukharrij al-hadis yakni orang yang meriwayatkan hadis sekaligus membukukan dalam sebuah kitab hadis. Istilah sederhana mukharrij al-hadis adalah orang yang membuat kitab hadis. Pada jalur sanad tersebut imam Abu Dawud menyadarkan periwayatnya pada rawi sebelumnya atau rawi yang tepat berada di atasnya yakni Ibrahim ibn Musa ibn Yazid ibn Zazan. Dalam ilmu hadis, kedudukan Ibrahim ibn Musa ibn Yazid ibn Zazan dalam jalur ini sebagai sanad pertama, sehingga dengan demikian sanad terakhirnya adalah ibn 'Abbas. Ibn Abbas juga disebut 
sebagai periwayat pertama, karena dia sebagai sahabat Rasulullah yang berstatus menjadi saksi pertama atas periwayatan hadis tentang puasa Rajab (Arifin, 2017).

Hadis riwayat Abu Daud di atas dinilai shahih oleh Syeikh Nasiruddin al-Abani dan dimasukkan oleh beliau kedalam kitab Shahih Sunan Abu Daud yang beliau periksa. Dengan demikian, terdapat dalil khusus yang shahih yang menaungi puasa Rajab (Mohd, 2018). Hadis ini pula yang dijadikan dasar oleh kalangan umat muslim bagi pelaksanaan puasa sunnah di bulan Rajab.

Hadis lain sebagai dijumpai dalam riwayat Muslim, Nabi Saw bersabda:

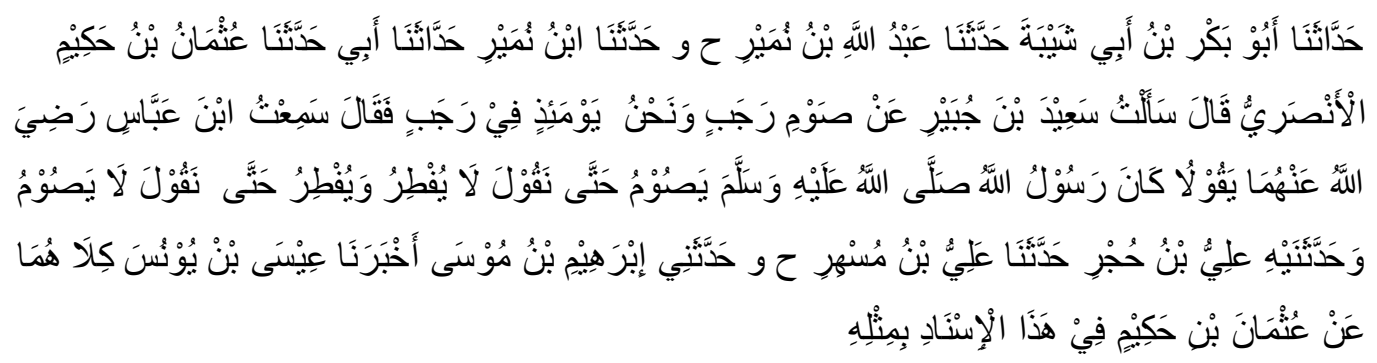

Artinya: Telah menceritakan kepada kami Abu Bakr bin Abu Syaibah telah menceritakan kepada kami Abdullah bin Numair dalam riwayat lain dan telah menceritakan kepada kami Ibnu Numair telah menceritakan kepada kami bapakku telah menceritakan kepada kami Utsman bin Hakim al-Anshari ia berkata; Saya bertanya kepada Sa'id bin Jubair mengenai puasa Rajab, dan saat itu kami berada di bulan Rajab. Maka ia pun menjawab Saya telah mendengar Ibnu Abbas Ra. berkata; Dulu Rasulullah Saw pernah berpuasa hingga kami berkata bahwa beliau tidak akan berbuka. Dan beliau juga pernah berbuka hingga kami berkata bahwa beliau tidak akan puasa." Dan telah menceritakannya kepadaku Ali bin Hujr telah menceritakan kepada kami Ali bin Mushir dalam riwayat lain dan telah menceritakan kepadaku Ibrahim bin Musa telah mengabarkan kepada kami Isa bin Yunus keduanya dari Utsman bin Hakim di dalam isnad ini, yakni dengan hadits semisalnya (Al-Hajjaj, 2016). 
KHAZANAH MULTIDISIPLIN

VOL 1 NO 22020

https://journal.uinsgd.ac.id/index.php/kl

Redaksi hadis yang menunjukkan tentang indikasi atau isyarat untuk melakukan puasa Rajab di atas diambil dari kitab Shahih Muslim. Oleh karenanya imam Muslim dalam jalur sanad hadis ini berkedudukan sebagai mukharrij al-hadis yakni orang meriwayatkan hadis sekaligus membukukannya menjadi kitab hadis. Sedangkan jalur sanad hadis tersebut bahwa imam Muslim menyandarkan periwayatannya pada rawi sebelumnya atau orang yang tepat berada di atasnya yakni Abu Bakar ibn Abi Syaibah dan Muhammad ibn Abdullah ibn Numair. Dengan demikian, istilah orang yang disandari oleh mukharrij al-hadis yakni imam Muslim tersebut dalam ilmu hadis disebut sebagai sanad pertama, dengan begitu secara otomatis ibn Abbas dalam jalur ini menjadi sanad terakhir (Arifin, 2017).

Imam Nawawi menjelaskan maksud hadis di atas bahwa maksud dari Sa'id bin Jubair mengemukakan dalil di atas, yakni Rasul Saw puasa dan tidak, adalah bahwa tidak ada larangan dan tidak ada pula anjuran terlebih perintah secara khusus pelaksanaan puasa pada Rajab, tetapi hukumnya sama seperti bulan-bulan lainnya. Tidak ada ketetapan larangan dan kesunnahan untuk pelaksanaan puasa Rajab tetapi asalnya puasa adalah Sunnah (Mohd, 2018). Kesimpulannya, yang tidak diperkenankan adalah berpuasa penuh sepanjang bulan Rajab, sedangkan banyak berpuasa di bulan Rajab tidaklah menjadi persoalan (Rosidin, 2016). Bahkan, hal itu diakui sebagai amalan yang baik.

Ada pula hadis yang diriwayatkan Imam Ahmad, Nabi Saw bersabda:

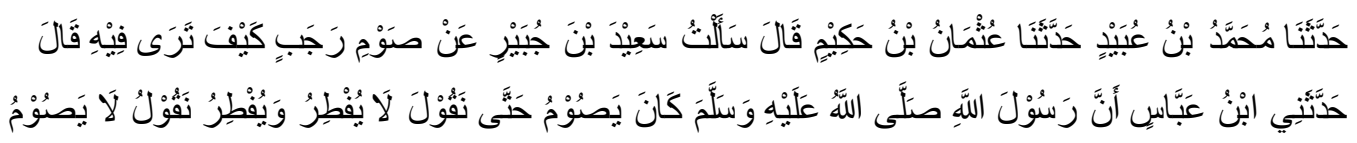

Artinya: Telah menceritakan kepada kami Muhammad bin Ubaid telah menceritakan kepada kami Utsman bin Hakim berkata; aku bertanya kepada Sa'id bin Jubair mengenai puasa Rajab, bagaimana menurutmu tentang itu? Ia menjawab; telah menceritakan kepadaku Ibnu Abbas bahwa 
KHAZANAH MULTIDISIPLIN

VOL 1 NO 22020

https://journal.uinsgd.ac.id/index.php/kl

Rasullah Saw seringkali berpuasa hingga kami katakan beliau tidak pernah berbuka, dan bila beliau juga sering tidak berpuasa hingga kami mengatakan beliau tidak pernah berpuasa (Ahmad No. 2854 dari Musnad bani Hasyim).

Redaksi hadis di atas diambil dari kitab Musnad Ahmad Ibn Hambal. Oleh karenanya Imam Ahmad dalam jalur sanad hadits ini berkedudukan sebagai mukharrij al-hadis yakni orang meriwayatkan hadis sekaligus membukukannya menjadi kitab hadis. Adapun pada jalur sanad hadis tersebut bahwa Imam Ahmad menyadarkan periwayatnnya pada rawi sebelumnya atau orang yang tepat berada di atasnya yakni Muhammad ibn 'Ubaid ibn Abi Umayah. Dengan demikian, istilah orangyang disandari oleh mukharrij al-hadis yakni imam Ahmad tersebut dalam ilmu hadis disebut sebagai sanad pertama, dengan begitu secara otomatis kedudukan ibn 'Abbas dalam jalur ini menjadi sanad terakhir (Arifin, 2017). Demikian di antara beberapa hadis berkenaan dengan puasa sunnah di bulan Rajab.

Adapun hadis tentang keutamaan bulan Rajab sebagai berikut:

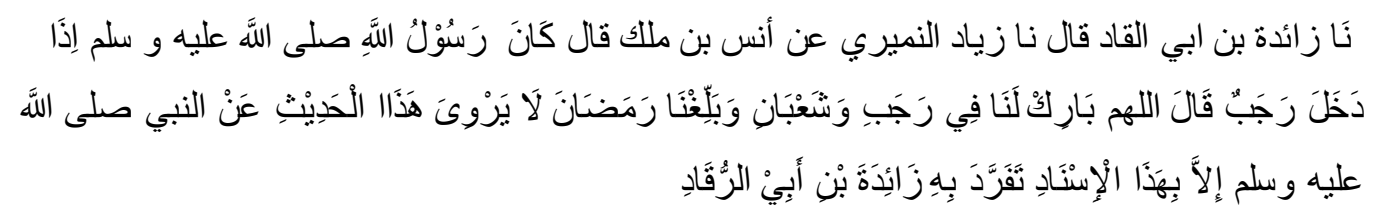

Artinya: Menceritakan kepada kami Zaidah ibn Abu ar-Ruqad, ia berkata menceritakan kepada kami Ziyad an-Numairi dari Anas ibn Malik, ia berkata: Apabila telah masuk bulan Rajab maka Rasulullah saw berdoa: Ya Allah! Berkahilah kamipada bulan Rajab dan Sya'ban dan sampaikanlah umur kami kepada bulan Ramadan. Tidak ada yang meriwayatkan Hadis ini kecuali dengan jalur sanad ini yaitu Zaidah ibn Abu ar-Ruqad" (Siregar, 2017).

Ulama sekaliber Ibn Taimiyah mengatakan bahwa seluruh hadis yang mengatakan kekhususan puasa sunnah pada bulan Rajab adalah hadis dhaif bahkan maudu' yakni sebagai hadisyang tertolak. Hal yang samajuga 


\section{KHAZANAH MULTIDISIPLIN}

VOL 1 NO 22020

https://journal.uinsgd.ac.id/index.php/kl

tentang puasa di bulan Rajab dikemukakan oleh Ibn Qayyim al-Jauziyah. Selebihnya, menurut Ibn Hajar, tidak ada hadis shahih yang menjelaskan keutamaan bulan Rajab, berpuasa di hari tertentu di bulan Rajab atau qiyam al-lail di hari tertentu di bulan Rajab (Siregar, 2017). Senada dengan ini, Baihaqi mengatakan bahwa tentang keutamaan berpuasa pada bulan Rajab ini ada beberapa hadis lain yang pada sanadnya atau jalur periwayatannya terdapat beberapa kelemahan. Di antaranya adalah hadishadis yang menyatakan bahwa Anas Ra. berkata, Rasulullah Saw bersabda, di surga ada sebuah sungai bernama Rajab yang warnanya lebih putih dari susu dan rasanya lebih manis dari madu. Dan barangsiapa berpuasa satu hari pada bulan Rajab, Allah kelak akan memberinya minum dari air sungai tersebut (Al-Baihaqi, 2007). Demikian, tampak para ulama tidak sependapat tentang adanya keutamaan pada bulan Rajab, dan bahkan ada pula hadis yang menyatakan terlarangnya shaum atau puasa di bulan Rajab (Sholehuddin, 2017).

Ibnu Majah meriwayatkan, bahwasannya Nabi Saw bersabda:

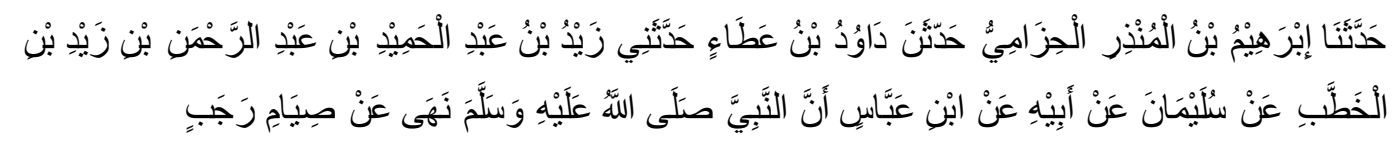

Artinya: Telah menceritakan kepada kami Ibrahim Ibnul Mundzir Al Hizami berkata: telah menceritakan kepada kami Dawud bin Atho berkata: telah menceritakan kepadaku Zaid bin Abdul Hamid bin 'Abdurrahman bin Zaid Ibnul Khaththab dari Sulaiman dari Bapaknya dari Ibnu Abbas berkata: Nabi Saw melarang puasa Rajab. Hadis No. 1733 atau Maktabatu al-Ma'arif Riyadh: 1743 (Sunan Ibnu Majah).

Jika dilihat paparan di atas, maka tampak bahwa hadis ini termasuk hadis yang melarang untuk melaksanakan puasa sunnah di bulan Rajab. Hadis ini diambil dari kitab Sunan ibn Majjah, sehingga dalam hal ini imam ibn Majjah kedudukannya sebagai mekharrij al-hadis karena dialah yang meriwayatkan hadis sekaligus membukukannya dalam sebuah kitab hadis. 


\section{KHAZANAH MULTIDISIPLIN}

VOL 1 NO 22020

https://journal.uinsgd.ac.id/index.php/kl

Kemudian orang yang diambil hadisnya oleh ibn Majjah atau orang yang disandari yakni periwayat yang tepat berada di atasnya yang lazim disebut sanad pertama. Dengan demikian yang menjadi sanad pertama dalam jalur hadits ini adalah Ibrahim ibn al-Mundir ibn 'Abd Allah al-Hizami sehingga ibn 'Abbas kedudukannya sebagai sanad terakhir. Hadis ini tidak memiliki syahid, dan mutabi' karena hadis ini hanya diriwayatkan oleh ibn Majjah saja (Arifin, 2017). Menurutteori ilmu hadis, mutabi' adalah sanadlain atau sanad yang lebih dari satu jalur dalam periwayatan suatu hadis, sedangkah syahid ialah matan lain atau matan yang lebih dari satu untuk suatu hadis dalam materi yang sama (Soetari, 1994).

Secara tegas dapat dikatakan bahwa puasa adalah salah satu bentuk peribadatan yang telah ditetapkan sebagai upacara ibadah (Syam, 2010). Juga puasa dipahami sebagai salah satu ibadah yang memiliki banyak manfaat, keutamaan, dan keajaiban yang luar biasa bagi siapapun yang menjalankannya (Syarbini, 2014). Bahkan, puasa diakui merupakan perbuatan hati (Abdullah, 2018). Dalam Islam, puasa merupakan salah satu ibadah yang memiliki nilai pahala besar (Kurniawati). Namun anjuran puasa pada bulan Rajab kurang ditunjang oleh hadis-hadis yang kuat dan para ulama menyatakan tidak ada keutamaan secara khusus di bulan Rajab (Siregar, 2017). Meskipun demikian terdapat pula hadis yang dinilai shahih oleh para ulama hadis bekenaan dengan puasa sunnah di bulan Rajab ini yakni hadis yang diriwayatkan oleh Abu Daud. Hal ini menunjukan pula bahwa bulan Rajab jelas memiliki keutamaan walapun bukan merupakan keutamaan secara khusus.

\section{Kontroversi Hadis Amalan Bulan Rajab}

Umat Islam di Indonesia ketika memasuki bulan Rajab kerap melangsungkan berbagai pelaksanaan amalan (Siregar, 2017). Termasuk pelaksanaan amalan puasa sunnah Rajab, namun terdapat perbedaan pendapat di antara ulama mengenai hukum melaksanakan puasa Rajab (Mohd, 2018). Perbedaan pendapat di kalangan para ulama tentang hukum 
KHAZANAH MULTIDISIPLIN

VOL 1 NO 22020

https://journal.uinsgd.ac.id/index.php/kl

berpuasa di bulan Rajab ini memang cukup jauh. Sebagian kalangan menetapkan bahwa hukumnya sunnah, sebagian lagi menyatakan sebagai makruh dan ada juga yang menyimpulkan haram atau bid'ah (Sarwat). Kenyataan ini menunjukan bahwa amalan puasa sunnah di bulan Rajab merupakan subjek yang kontroversial di kalangan umat muslim di Indonesia.

Sehubungan dengan pandangan kontriversial di seputar puasa sunnah bulan Rajab, ada baiknya untuk dikemukakan beberapa komentar para ulama hadis berkenaan dengan hal tersebut. Pertama, Ibnu shalah dan lain-lain mengatakan bahwa tidak benar adanya hadis shahih tentang shaum atau puasa Rajab, baik berupa larangan maupun anjuran. Berkenaan dengan ini, asal shaum adalah disukai pada bulan Rajab atau bulan-bulan lainnya.Kedua, Ibnu Rajab berkata, tidak ada satu pun yang shahih tentang keutamaan shaum Rajab secara khusus, baik dari Nabi Saw. maupun dari para sahabatnya. Ketiga, Abdur Rauf al-Manawi mengatakan, dalam Kitab al-Shiratal Mustaqin disebutkan, bahkan hadis-hadis yang menyatakan datang dari Nabi Saw. tentang shaum Rajab adalah dusta belaka. Keempat, Imam Nawawi mengatakan, tidak datang dari Nabi Saw. anjuran atau larangan (Sholehuddin, 2017). Kelima, Imam Ibnu Hajar al-Asqalani (852 H.) dalam kitabnya Tabyin Al-'Ajab bi Ma Warad fi Fadhl Rajab menyebutkan bahwa tidak ada satu pun hadits yang valid atau sahih tentang fadhilah atau keutamaan puasa pada Rajab (Waskito, 2016). Keenam, menurut Imam Ibn Taimiyyah puasa bulan Rajab secara khusus tidak boleh dilakukan karena tidak ada tuntunannya dari Nabi dan sahabat sebagaimana yang dijelaskan di dalam kitabnya Majmu' Fatawa (Mohd, 2018). Ketujuh, Imam Syaukani menjelaskan adanya dalil-dalil, baik yang umum maupun khusus, yang shahih ataupun dhaif tentang puasa di bulanbulan haram menunjukkan bahwa puasa pada bulan-bulan tersebut disyariatkan (Mohd, 2018).

Pada bulan Rajab pada dasarnya tidak ada amalan yang dikhususkan, bila pun ada maka hal itu perlu untuk dikonfirmasi dan 


\section{KHAZANAH MULTIDISIPLIN}

VOL 1 NO 22020

https://journal.uinsgd.ac.id/index.php/kl

diklarifikasi keshahihan hadisnya atau sumbernya, namun anjuran untuk berbuat kebaikan dan menjauhi kemaksiatan di dalamnya jelas bukan hal yang keliru, hanya saja bukan berarti mengkhususkan beberapa amalan tertentu (Setiyanto, 2016). Daripada itu, hukum yang berkaitan dengan bulan Rajab amatlah banyak. Ada beberapa hukum yang sudah ada dan ditemukan sejak masa Jahiliyah. Dalam hal ini, memang para ulama berselisih pendapat apakah hukum ini masih tetap berlaku ketika datang Islam ataukah tidak berlaku lagi. Di antaranya yang paling tegas adalah haramnya peperangan ketika bulan haram tentunya termasuk bulan Rajab. Berkenaan dengan ini, para ulama tampak berselisih pendapat apakah nasakh ataukah mansukh atau dihapus hukumnya. Mayoritas ulama menganggap bahwa hukum tersebut telah dihapus dalam arti tidak diteruskan menjadi landasan Islam. Ibnu Rajab mengatakan, tidak diketahui dari satu orang sahabat pun bahwa mereka berhenti berperang pada bulan-bulan haram, padahal ada faktor pendorong ketika itu. Kenyataan ini menunjukkan bahwa mereka sepakat tentang dihapusnya hukum tersebut (As-Syaqiry, 2004). Dapat dinyatakan bahwa hukum puasa sunah Rajab sesuai kesepakatan tiga Imam Mazhab adalah sunah, dalam hal ini kecuali Imam Hambali yang berpendapat bahwa puasa pada bulan Rajab secara tersendiri itu hukumnya makruh, namun jika tidak berpuasa di pertengahan bulan, hal itu tidak makruh (Ahmad, 2007).

Terasa sekali bahwa amalan puasa pada bulan Rajab tidak cukup dijelaskan hanya dengan pendekatan syariat atau hukum Islam saja. Secara hukum jelas bahwa puasa memiliki pahala kebaikan bagi yang melaksanakannya termasuk di bulan Rajab. Oleh karena itu, amalan puasa di bulan Rajab dibutuhkan pengkajian secara komprehensif, integral, dan mendalam. Salah satunya pendekatan kontekstual dalam memahami hadis. Melalui pendekatan ini maka hadis akan dipahami sesuai konteksnya (Subhan, 2011). Selebihnya diperlukan pula kajian hadis berkenaan dengan nilai-nilai Islam yang mentradisi di masyarakat. Amal an puasa mempunyai nilai-nilai luhur dari ajaran Islam sehingga pelaksanaannya dapat 


\section{KHAZANAH MULTIDISIPLIN}

VOL 1 NO 22020

https://journal.uinsgd.ac.id/index.php/kl

menghadirkan nilai-nilai kebaikan pula dalam tradisi masyarakat. Sehubungan dengan ini dibutuhkan penelitian living hadis tentang amalan puasa sunnah di bulan Rajab. Penelitian living sendiri bertujuan menggali nilai-nilai Islam yang bertranformasi dalam kehidupan di masyarakat (Darmalaksana, Alawiah, Thoyib, Sadi'ah, \& Ismail, 2019). Apabila amalan sunnah di bulan Rajab dilakukan secara holistik dari berbagai pendekatan keilmuan, maka dipastikan hal tersebut tidak akan menjadi subjek yang kontroversial lagi di masyarakat Indonesia.

\section{SIMPULAN}

Berdasarkan referensi-referensi yang tersedia serta hadis-hadis yang menjadi kontroversi amalan sunnah bulan Rajab bahwasannya tidak ada amalan pengkhususan pada saat bulan Rajab tetapi sangat dianjurkan setiap umat Islam sebagai hamba Allah untuk selalu meningkatkan ketakwaan kepada Allah dan meningkatkan amalan ibadah kapanpun dan dimanapun berada. Penelitian ini diharapkan memiliki implikasi manfaat bagi khalayak umat muslim tinjauan hukum Islam berkenaan dengan amalan puasa sunnah bulan Rajab. Penelitian ini disadari memiliki keterbatasan khususnya dalam penyajian syarah hadis sehingga dibutuhkan penelitian lebih lanjut melalui pendekatan yang lebih kontekstual. Penelitian ini merekomendasikan terutama bagi para peneliti bidang hadis untuk melakukan pendalaman mengenai nilai-nilai amalan puasa sunnah bulan Rajab melalui pendekatan living hadis den gan analisisanalisis ilmu sosial.

\section{DAFTAR PUSTAKA}

Abdullah, I. (2018). Mukjizat Ibadah. Pustaka Media.

Achmad, H. (2007). Meraih Surga Dengan Puasa. Jakarta: Puswa Swara. Ahmad, H. (2007). Meraih Surga dengan Puasa. Jakarta: Puspa Swara. Al-Baihaqi, A. B.-H. (2007). Waktu-waktu Penuh Berkah: Khazanah Islam Klasik. Jakarta: Qisthi Perss. 
KHAZANAH MULTIDISIPLIN

VOL 1 NO 22020

https://journal.uinsgd.ac.id/index.php/kl

Al-Ballawi, S. M.-H. (2016). Buku Pintar Sejarah Peradaban Islam. (Artawijaya, Ed., m. Irham, \& M. Supar, Trans.) Jakarta: Pustaka AlKautsar.

Al-Hajjaj, I. M. (2016). Terjemahan Kitab Puasa Shahih Muslim. Semarang: Maktabah Isma'il bin 'Isa.

Al-Qahthani, S. b. (2004). Buku Putih Syaikh Abdul Qadir Al-Jailani. Jakarta: Darul Falah.

Al-Qummi, A. (2008). Mafatih al-Jinan; Kunci-kunci Surga. Jakarta: AlHuda.

Alviennoer, A. (2010). Pemahaman Asyhur Al-Hurum dalam Hijriah Menurut Prespektif Hadis. Jakarta: UIN Syarif Hidayatullah.

Anshary, H. (2013). Fiqih Kontroversi Beribadah antara Sunnah dan Bid'ah. Bandung: Tafakur.

Arifin, M. (2017). Menguji Autentitas Hadis-Hadis tentang Pengamalan Puasa Rajab (Kajian Terhadap Sanad dan Matan). Tulungagung: IAIN Tulungangung.

Asiyah, U. (2016). Dakwah Kreatif : Muharram, Maulid Nabi, Rajab dan Sya'ban. Jakarta: PT. Gramedia Pustaka Utama.

As-Sijistani, A. D.-A. (2007). Kitab Puasa Sunan Abu Dawud. Semarang: Maktabah Ismail bin 'Isa.

As-Syaqiry, M. '.-s. (2004). Bid'ah-Bid'ah yang Dianggap Sunnah. Jakarta: Qisthi Press.

Azkiya, N. (2019). Syauqillah. AE Publishing.

Darmalaksana, W. (2018). Paradigma Pemikiran Hadis. Jurnal Aqidah dan Filsafat Islam, 95-106.

Darmalaksana, W. (2020). Cara Menulis Proposal Penelitian. Bandung: Fakultas Ushuluddin UIN Sunan Gunung Djati Bandung.

Darmalaksana, W. (2020). Formula Penelitian Pengalaman Kelas Menulis. Kelas Menulis UIN Sunan Gunung Djati Bandung.

Darmalaksana, W. (2020). Kelas Menulis dari Proposal ke Artikel Ilmiah, Publikasi.Jurnal dan Hak Kekayaan Intelektual. (W. Darmalaksana, Ed.) Bandung: Sentra Publikasi Indonesia. 
KHAZANAH MULTIDISIPLIN

VOL 1 NO 22020

https://journal.uinsgd.ac.id/index.php/kl

Darmalaksana, W. (2020). Metode Penelitian Penelitian Kualitatif Studi Pustaka dan Studi Lapangan. Pre-Print Digital Library UIN Sunan Gunung Djati Bandung.

Darmalaksana, W.(2020). Pemetaan Penelitian Hadis: Analisis Skripsi UIN Sunan Gunung Djati Bandung. Riwayah: Jurnal Studi Hadis, 191210.

Darmalaksana, W. (2020). Studi Penggunaan Analisis Pendekatan Ilmuilmu Sosial dalam Penelitian Hadis Metode Syarah. Khazanah Sosial, 2(3), 155-166.

Darmalaksana, W., Alawiah, N., Thoyib, E. H., Sadi'ah, S., \& Ismail, E. (2019). Analisis Perkembangan Penelitian Living Al-Qur'an dan Hadis. Jurnal Perspektif.

Darmalaksana, W., Pahala, L., \& Soetari, E. (2017). Kontroversi Hadis sebagai Sumber Hukum Islam. Wawasan: Jurnal Ilmiah Agama dan Sosial Budaya.

Dhohir, R. I. (2019). Kualitas Hadis-Hadis Viral tentang Keutamaan Bulan Rajab. Jakarta: Jurnal Studi Ilmu Al-Qur'an dan Tafsir.

Khozinatin, L. (2017). Keutamaan Puasa Sunnah Dalam Prespektif Hadis (Kajian Tematik). Jakarta: UIN Jakarta.

Kurniawati, V. (n.d.). Puasa Antara Yang Masyru' dan Tiadak Masyru'. Lentera Islam.

Mohd, A.-S. R. (2018). Hukum Puasa Rajab Studi Kompratif Antara Imam Al-Nawawi dan Imam Ibnu Taimiyyah. Riau: UIN SUSKA.

Rosidin. (2016). Mata Air Dakwah. Malang: Media Surya Atiga .

Sarwat, A. (n.d.). Masuk Neraka Gara-gara Puasa Rajab? Lentera Islam.

Setiyanto, D. A. (2016). Sebah Catatan Sosial Tentang Ilmu, Islam, dan Indonesia. Yogyakarta: Deepublish.

Shohibah, I. F. (2012). Mengenal Nama Bulan dalam Kalender Hijriyah. Jakarta: PT. Balai Pustaka.

Sholehuddin, W. S. (2017). Risalah Shaum: Telaah Kritis atas SunahSunah dan Bid'ah-Bid'ahnya. Bandung: Tafakur.

Sholikhin, M. (2010). Misteri Bulan Suro Perspektif Islam Jawa. Yogyakarta: Penerbit Narasi. 
KHAZANAH MULTIDISIPLIN

VOL 1 NO 22020

https://journal.uinsgd.ac.id/index.php/kl

Siregar, M. N. (2017). Reinterprestasi Hadis tentang Keutamaan Bulan Rajab dan Ramadhan. Shahih : Jurnal Kewahyuan Islam, 58.

Sodiqin, A. (2008). Antropologi Al-Qur'an: Model Dialektika Wahyu dan Budaya.

Soetari, E. (1994). Ilmu Hadits. Bandung: Amal Bakti Press.

Subhan, S. (2011). Hadis Kontekstual: Suatu Kritik Matan Hadis. Mazahib.

Sunan Ibnu Majah. (n.d.).

Syam, Y. H. (2010). Puasa sepanjang Tahun. Yogyakarta: Mutiara Media.

Syarbini, A. (2014). The Miracle of Fast. Jakarta: PT Elex Media Komputindo.

Waskito, A. (2016). KH. Ali Mustafa Yaqub Menjaga Sunnah Mengawal Aqidah. Jakarta: Pustaka Al-Kautsar.

Zahra, T. (2005). Doa \& Amalan di Bulan Rajab, Sya'ban \& Ramadhan. Jakarta: Zahra Publishing House. 